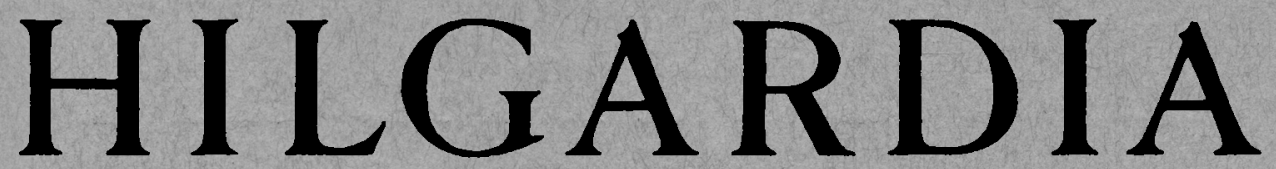

A Journal of Agricultural Science Published by the California Agricultucral Experiment Station

RESPONSE OF THOMPSON SEEDLESS GRAPES

TO 4-CHLOROPHENOXYACEIC ACID AND BENZOTHIAZOL-2-OXYACEIC ACID

ROBERT J. WEAVER and STANLYY B. MCCUNE 


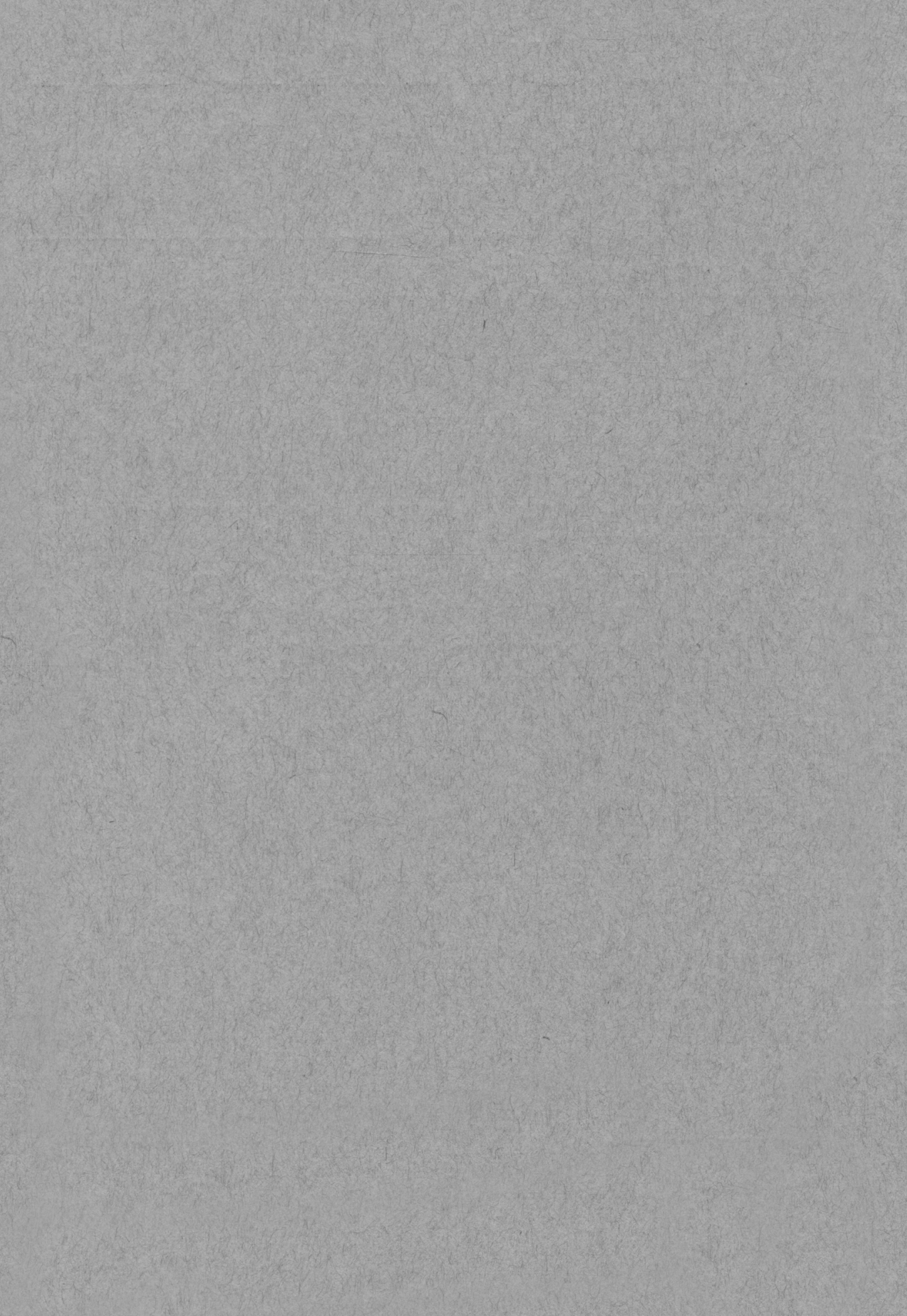




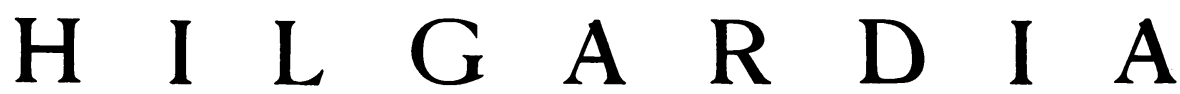

A Journal of Agricultural Science Published by

the California Agricultural Experiment Station

VoL. 27

OCTOBER, 1957

No. 6

\section{RESPONSE OF THOMPSON SEEDLESS GRAPES TO 4-CHLOROPHENOXYACETIC ACID AND BENZOTHIAZOL-2-OXYACETIC ACID ${ }^{1}$}

\author{
ROBERT J. WEAVER ${ }^{2}$ and STANLEY B. MCCUNE ${ }^{3}$
}

\section{INTRODUCTION}

THIS PAPER presents the results of two studies of plant regulators, one on 4-chlorophenoxyacetic acid (4-CPA) (also known as para-chlorophenoxyacetic acid or PCPA), the other on benzothiazol-2-oxyacetic acid (BOA).

The plant regulator 4-chlorophenoxyacetic acid (4-CPA) has been used commercially to increase berry size in Thompson Seedless grapes $(2,5,6){ }^{4}$ There have been for some time, however, several problems relating to its use that have required further study. One question concerned the importance of the foliage as an avenue for entry of the compound into the fruit. Another was whether the use of 4-CPA resulted in a delay in ripening. Still another problem concerned the influence of the level of cropping on the response to the compound. These problems formed the basis of our experiments with 4-CPA, which extended over a four-year period.

The second plant regulator studied-benzothiazol-2-oxyacetic acid (BOA) - has been shown to cause a delay in ripening in Thompson Seedless $(3,4)$. In 1955 and 1956 the following studies were made in California in order to obtain further and more detailed information: The effect of various concentrations of benzothiazol-2-oxyacetic acid on Thompson Seedless; the relation of stage of development of the vine to application of the regulator; and the effect of the compound on rate of ripening of fruit.

\section{MATERIALS AND METHODS}

Mature vines of Thompson Seedless in irrigated vineyards were pruned to four or five canes bearing from eight to 12 buds for the experiment.

In the University of California vineyards at Davis, the ammonium salt of 4-chlorophenoxyacetic acid was used, and the diethanolamine salt of the acid was utilized in the trials in commercial vineyards. The sodium salt of benzo-

\footnotetext{
${ }^{1}$ Received for publication February 28, 1957.

${ }^{2}$ Lecturer and Associate Viticulturist in the Experiment Station, Davis.

${ }^{3}$ Senior Laboratory Technician in the Department of Viticulture, Davis.

" Figures appearing in parentheses indicate "Literature Cited."
} 
thiazol-2-oxyacetic acid was used in all experiments. The concentrations of each compound expressed as ppm are on an acid-equivalent basis. Dreft was added to the aqueous solutions as a wetting agent. At Davis, sprays were applied with a 3-gallon hand sprayer, usually to individual canes selected at random along the rows. When necessary, cardboard shields were used to confine the spray to the intended area. In the other vineyards entire vines were sprayed, usually with commercial-type sprayers.

In experiments performed at Davis, vines were cluster thinned to five per cane after the normal drop of berries following flowering (7). All clusters were removed from the head of the vine. The retained clusters were berry thinned by cutting off the apical half of the cluster, leaving five or six main branches of the rachis (7).

At Davis all the fruit from experiments done on a cane basis was harvested, while in the various other commercial vineyards only approximately 30 pounds of fruit were obtained from each treatment, one cluster usually being removed from each vine. At the times of sampling, weight of berry was obtained to indicate size of berry. About half the berries were removed from each cluster, thoroughly mixed, and the weight of 200 berries selected at random determined in duplicate. The expressed juice was used to determine total acidity, and percentage of total soluble solids expressed as degrees Balling (2).

\section{Experimentation and Results with 4-chlorophenoxyacetic Acid (4-CPA)}

Influence of Regulator Absorbed by Leaves on Fruit. The purpose was to determine whether 4-chlorophenoxyacetic acid (4-CPA) absorbed by the leaves increases size of berry, as was indicated in a previous experiment (2). In 1954 Thompson Seedless vines at Davis were cluster and berry thinned on June 7 . The clusters in one lot were enclosed in waxed-paper bags before the vines were thoroughly sprayed with 4 -CPA at $15 \mathrm{ppm}$. After the spray had dried, the bags were removed. The clusters on another lot of canes were treated by dipping in solutions of 4 -CPA at $15 \mathrm{ppm}$. In another lot the foliage was sprayed and the clusters were dipped, while still another lot served as the untreated controls. There were 10 replicate canes per lot in each treatment. Fruit was harvested on August 18.

The data (table 1) indicate that the greatest increase in berry size resulted when the foliage was sprayed in addition to the fruit being dipped. However, almost as great an increase occurred when the foliage only was sprayed. The increase in berry size resulting from the dipping of clusters only was merely about two thirds of that resulting from the other two treatments with 4-CPA in which the leaves were sprayed.

This experiment was repeated in 1955. Thinning and spraying were performed on June 9, and fruit harvested on September 6 . The results (table 1) are in general agreement with those of 1954.

Influence of 4-chlorophenoxyacetic Acid on Rate of Ripening. The purpose of these experiments was to determine whether 4-CPA delays maturation. For this study it was necessary to eliminate the effect of crop level by 
making the weight of crop on sprayed and unsprayed canes as nearly equal as possible. This was done by thinning more severely canes which were to be sprayed.

Canes were cluster thinned to five or seven clusters, and the retained clusters berry thinned. One lot of canes with five and one with seven clusters

TABLE 1

THE EFFECT OF AMMONIUM SALT OF 4-CHLOROPHENOXYACETIC ACID

AT 15 PPM APPLIED TO FOLIAGE AND/OR FRUIT OF THOMPSON

SEEDLESS GRAPES AT DAVIS, CALIFORNIA

\begin{tabular}{|c|c|c|c|}
\hline Treatment & $\begin{array}{l}\text { Weight } \\
\text { per berry } \\
(\mathrm{gm})\end{array}$ & $\begin{array}{c}\text { Percentage } \\
\text { of total } \\
\text { soluble } \\
\text { solids }\end{array}$ & $\begin{array}{c}\text { Percentage } \\
\text { of acid }\end{array}$ \\
\hline & \multicolumn{3}{|c|}{$1954^{*}$} \\
\hline Leaves not sprayed, clusters not dipped $\ldots \ldots \ldots \ldots \ldots \ldots \ldots \ldots$ & 1.79 & 20.4 & 0.63 \\
\hline 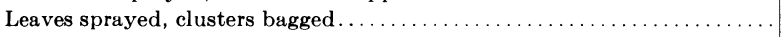 & 2.14 & 19.5 & 0.64 \\
\hline Leaves not sprayed, clusters dipped $\ldots \ldots \ldots \ldots \ldots \ldots \ldots \ldots \ldots \ldots \ldots$ & 2.03 & 19.5 & 0.66 \\
\hline \multirow[t]{2}{*}{ 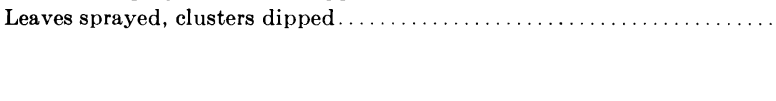 } & 2.16 & 20.1 & 0.60 \\
\hline & \multicolumn{3}{|c|}{$1955 \dagger$} \\
\hline Leaves not sprayed, clusters not dipped. & 1.88 & 19.2 & 0.56 \\
\hline Leaves sprayed, clusters bagged........ & 2.43 & 18.0 & 0.59 \\
\hline Leaves not sprayed, clusters dipped. & 2.18 & 17.1 & 0.68 \\
\hline Leaves sprayed, clusters dipped...... & 2.47 & 16.6 & 0.63 \\
\hline
\end{tabular}

* Significant difference between means for weight of berries at 5 per cent is 0.21 .

$\dagger$ Significant difference between means for weight of berries at 5 per cent is 0.26 .

were girdled and a similar lot was not girdled. Both girdled and ungirdled canes bearing five clusters were sprayed with 4-CPA at a concentration of $15 \mathrm{ppm}$ with the expectation that their final crop weight would be about equal to the corresponding unsprayed canes bearing seven clusters. It had been previously found that regulator increased crop weight by about 30 per cent (6). If crop weights were about equal any difference in degree Balling reading might then be attributed to the plant regulator.

In 1953 thinning, cane girdling, and spraying were done on June 8, and the fruit was harvested on September 1 (table 2). There were 10 replicate canes per treatment in this experiment and in the succeeding three years when the experiment was repeated, except for 1955 when there were six. The girdled, sprayed vines had a lower degree Balling reading than the corresponding girdled, not sprayed vines, in spite of the fact that the former vines had a lower crop. The differences were smaller with the ungirdled vines.

In 1954 thinning was done on June 6 and girdling and spraying on June 8. The fruit was harvested on August 24 (table 2). There is an indication that the regulator caused a slight delay in maturity in both girdled and ungirdled vines.

In 1955 cane girdling and thimning were done on June 8 and the spray applied one day later. Fruit was harvested on August 21, and apparently only the ripening of the ungirdled, sprayed fruit was delayed. 
In 1956 thinning was done on June 4, girdling on June 6, and spraying on June 12. Only girdled canes were utilized. Slight if any differences in rate of ripening were noted (table 2 ).

Although statistical analyses show that spraying significantly delayed degree Balling in only two instances, the data of table 2 indicate that when

TABLE 2

THE EFFECT OF THE AMMONIUM SALT OF 4-CHLOROPHENOXYACETIO ACID APPLIED AT 15 PPM ON RATE OF MATURATION OF THOMPSON SEEDLESS GRAPES

\begin{tabular}{|c|c|c|c|c|c|}
\hline Treatment & $\begin{array}{l}\text { Av. number } \\
\text { of clusters } \\
\text { per cane } \\
\text { at harvest }\end{array}$ & $\begin{array}{l}\text { Av. weight } \\
\text { of fruit } \\
\text { per cane } \\
\text { (lb) }\end{array}$ & $\begin{array}{c}\text { Av. weight } \\
\text { per berry } \\
\text { (gm) }\end{array}$ & $\begin{array}{c}\text { Percentage } \\
\text { of total } \\
\text { soluble } \\
\text { solids }\end{array}$ & $\begin{array}{c}\text { Percentage } \\
\text { of acid }\end{array}$ \\
\hline & \multicolumn{5}{|c|}{1953} \\
\hline Not girdled, not sprayed .......... & 7.1 & 5.4 & 1.35 & 19.9 & 1.00 \\
\hline Not girdled, sprayed........... & 4.9 & 5.6 & 1.57 & 19.0 & 0.93 \\
\hline Girdled, not sprayed $\ldots \ldots \ldots \ldots \ldots \ldots \ldots \ldots$ & 6.9 & $10.9^{*}$ & 1.70 & 17.3 & 1.09 \\
\hline \multirow[t]{2}{*}{ 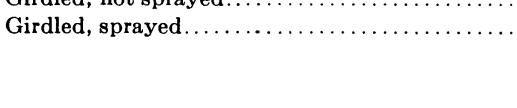 } & 5.4 & $8.2^{*}$ & 1.96 & 16.1 & 1.18 \\
\hline & \multicolumn{5}{|c|}{1954} \\
\hline Not girdled, not sprayed. & 7.2 & 7.5 & 1.53 & $20.5 \dagger$ & 0.69 \\
\hline Not girdled, sprayed........ & 5.0 & 7.2 & 1.95 & $18.3 \dagger$ & 0.77 \\
\hline Girdled, not sprayed $\ldots \ldots \ldots \ldots \ldots \ldots \ldots$ & 7.3 & 11.1 & 2.15 & 15.4 & 0.86 \\
\hline \multirow[t]{2}{*}{ Girdled, sprayed $\ldots \ldots \ldots \ldots \ldots \ldots \ldots \ldots \ldots \ldots \ldots$} & 5.4 & 9.2 & 2.62 & 14.0 & 0.87 \\
\hline & \multicolumn{5}{|c|}{1955} \\
\hline Not girdled, not sprayed. & $\ldots$ & 7.2 & 1.64 & $19.8 \dagger$ & 0.79 \\
\hline Not girdled, sprayed..... & $\ldots$ & 8.7 & 2.43 & $17.5 \dagger$ & 0.77 \\
\hline Girdled, not sprayed $\ldots \ldots \ldots \ldots \ldots \ldots \ldots \ldots$ & $\ldots$ & 11.5 & 2.28 & 13.0 & 1.11 \\
\hline \multirow{2}{*}{ Girdled, sprayed $\ldots \ldots \ldots \ldots \ldots \ldots \ldots \ldots \ldots \ldots$} & $\ldots$ & 10.1 & 2.56 & 12.8 & 1.05 \\
\hline & \multicolumn{5}{|c|}{1956} \\
\hline Girdled, not sprayed $\ldots \ldots \ldots \ldots \ldots \ldots \ldots \ldots$ & 6.7 & 12.4 & 2.38 & 16.0 & 0.63 \\
\hline 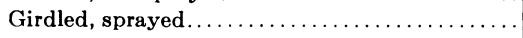 & 4.9 & 13.2 & 3.36 & 15.8 & 0.70 \\
\hline
\end{tabular}

* The significant difference between means for weight of fruit per cane at 5 per cent is 2.5 . All other pairs are not significantly different.

$\dagger$ The significant difference between means for percentage of total soluble solids at 5 per cent is 1.0 in 1954 and 1.8 in 1955. All other pairs are not significantly different.

weight of crop is taken into consideration maturation of sprayed fruit was slightly delayed in three or four cases out of seven.

Influence of Level of Crop on Response to 4-CPA. The purpose was to determine the effect of various levels of crop on response of the fruit to applications of 4-CPA. The response was measured by determining increase in size of berry and in changes in the degree Balling reading or percentage of acid.

Experiment in 1953. On June 9, canes were cluster thinned to four, six, 
or eight clusters. One set of canes at each level of crop was sprayed with 4-CPA at $15 \mathrm{ppm}$ on June 10. Another set at each level of crop was used as the unsprayed controls. There were 10 replicate canes per treatment. The fruit was harvested on September 11 (table 3). In this experiment canes bearing eight clusters had a smaller berry size on both sprayed and unsprayed

TABLE 3

INFLUENCE OF LEVEL OF CROP IN THOMPSON SEEDLESS TO RESPONSE TO 4-CHLOROPHENOXYACETIC ACID APPLIED AT 15 PPM AT DAVIS, CALIFORNIA

\begin{tabular}{|c|c|c|c|c|}
\hline Thinning and spray treatment & $\begin{array}{l}\text { Av. weight } \\
\text { of crop } \\
\text { per cane } \\
\text { (lb) }\end{array}$ & $\begin{array}{l}\text { Av. weight } \\
\text { per berry } \\
\text { (gm) }\end{array}$ & $\begin{array}{l}\text { Percentage } \\
\text { of total } \\
\text { soluble } \\
\text { solids }\end{array}$ & $\begin{array}{l}\text { Percentage } \\
\text { of acid }\end{array}$ \\
\hline & \multicolumn{4}{|c|}{$1953^{*}$} \\
\hline 4 clusters per cane, not sprayed... & 4.2 & 1.34 & 23.4 & 0.78 \\
\hline 6 clusters per cane, not sprayed........... & 5.0 & 1.31 & 23.7 & 0.77 \\
\hline 8 clusters per cane, not sprayed........ & 6.3 & 1.21 & 23.4 & 0.78 \\
\hline 4 clusters per cane, sprayed $\ldots \ldots \ldots \ldots \ldots \ldots \ldots \ldots \ldots$ & 4.4 & 1.52 & 24.6 & 0.71 \\
\hline 6 clusters per cane, sprayed $\ldots \ldots \ldots \ldots \ldots \ldots \ldots \ldots \ldots$ & 7.6 & 1.55 & 22.2 & 0.77 \\
\hline \multirow[t]{2}{*}{8 clusters per cane, sprayed $\ldots \ldots \ldots \ldots \ldots \ldots \ldots \ldots \ldots \ldots \ldots \ldots \ldots \ldots \ldots$} & 8.5 & 1.45 & 22.6 & 0.74 \\
\hline & \multicolumn{4}{|c|}{$1955 \dagger$} \\
\hline 5 clusters per cane, not sprayed... & 9.2 & 2.40 & 15.9 & 0.63 \\
\hline 10 clusters per cane, not sprayed.$\ldots \ldots \ldots \ldots \ldots \ldots \ldots \ldots \ldots$ & 12.5 & 1.91 & 15.3 & 0.71 \\
\hline 5 clusters per cane, sprayed $\ldots \ldots \ldots \ldots \ldots \ldots \ldots \ldots \ldots \ldots$ & 12.4 & 2.91 & 13.7 & 0.78 \\
\hline 10 clusters per cane, sprayed $\ldots \ldots \ldots \ldots \ldots \ldots \ldots \ldots \ldots \ldots$ & 10.5 & 1.87 & 12.3 & 0.83 \\
\hline
\end{tabular}

* In 1953, the significant difference between means for weight of berries on sprayed and not sprayed canes having equal number of clusters is $0.11 \mathrm{gram}$. The differences were not significant among the mean weights of berries in the 4-, 6-, or 8-cluster canes, whether sprayed or not sprayed.

+ The difference for weight of berries between sprayed and corresponding not sprayed canes in 1955 was not significant. The significant difference for weight of berry between the 5- and 10-cluster canes, both sprayed and not sprayed, is $0.33 \mathrm{gram}$.

canes. All sprayed fruit developed larger berries than the corresponding controls. If the vines had been girdled perhaps there would have been a sufficiently heavy crop to reduce the response to the regulator. The decreased degree Balling reading of fruit from sprayed canes bearing six or eight clusters may be attributed to the increased crop.

Experiment in 1955. Two levels of crop were used. Canes were thinned to five or 10 clusters early in June. Sets of canes with five or 10 clusters were sprayed on June 9, and similar sets served as the unsprayed controls. All canes were girdled on June 10 . There were 10 replicate canes per treatment. Fruit was harvested on September 9.

The data (table 3) show that the regulator increased berry size when there were five clusters per cane, but that there was no increase when there were 10 clusters per cane. Thus overcropped vines respond poorly or not at all to 4-CPA. The weight of berry was determined to be significantly less at the 5 per cent level on canes bearing 10 clusters than on corresponding canes bearing five clusters in case of both unsprayed and sprayed fruit. This 
experiment also sheds light on the effect of 4-CPA in delaying maturity. Although the weight of crop in the sprayed five-cluster treatment was about the same as in the unsprayed 10-cluster treatment, the degree Balling reading was lower and percentage of acid higher in fruit from the sprayed canes.

\section{Experimentation and Results with Benzothiazol-2-oxyacetic Acid (BOA)}

\section{Effect of Various Concentrations}

Experiments were performed at Davis and in some of the important areas for growing Thompson Seedless in California to determine the proper concentration of BOA for best results.

\section{Results in 1955}

Yolo County (Davis). Cluster thinning and berry thinning were done in early June, 1955. Canes were girdled and sprayed with BOA at concentrations of $0,1,2 \frac{1}{2}, 5,10$ or $20 \mathrm{ppm}$ on June 10 . There were 10 canes per treatment. The fruit was harvested on September 14. There were some typical cup-shaped leaves resulting from the BOA on vines sprayed with compound at a concentration of $20 \mathrm{ppm}$ (4). Very few or no misshapen leaves were found on vines sprayed with lower concentrations. This situation held true in the subsequent experiments with BOA. Berries from canes sprayed with BOA at concentrations of 10 or $20 \mathrm{ppm}$ appeared greener than control fruit. However, fruit sprayed at $20 \mathrm{ppm}$ had some small berries interspersed among the larger. There was no significant difference in size of berry (table 4). The degree Balling reading was depressed and a higher percentage of acid was retained by the sprayed fruit. The latter differences, however, were not significant.

Stanislaus County (Modesto). The vines were cluster thinned to about 20 clusters per vine, and the retained clusters were very lightly berry thinned by cutting off about the apical fifth of each cluster. Cane girdling and spraying were done on June 23, 1955, 10 vines per treatment, and samples were collected on September 2 (table 4 ). The compound at $20 \mathrm{ppm}$ decreased berry size and retarded maturation; BOA at 5, 10, or $20 \mathrm{ppm}$ resulted in a higher retention of total acid.

Fresno County (Sanger). The vines usually bearing four canes were cluster thinned to six clusters per cane, and these clusters were berry thinned by removing the apical half or two thirds of the cluster. Vines were cane girdled on June 9 and sprayed on June 10. The compound at $15 \mathrm{ppm}$ decreased degree Balling and resulted in a greater retention of acid (table 4).

Tulare County (Terra Bella). These vines usually had four canes and were cluster thinned to about 20 clusters per vine. Retained clusters were berry thinned. Spraying and trunk girdling were performed on June 11 and samples were collected on August 22. Although there was a heavy powdery mildew infestation in the vineyard, results were similar to those previously obtained (table 4 ).

Kern County (Delano). Vineyard No. 1 had vines bearing 25 to 30 clusters and usually four canes. Cluster thinning, berry thinning, and spraying were done on June 3,1955 . About one fourth of each cluster was 
TABLE 4

EFFECT OF VARIOUS CONCENTRATIONS OF BENZOTHIAZOL-2-OXYACETIC ACID ON THOMPSON SEEDLESS GRAPES IN 1955

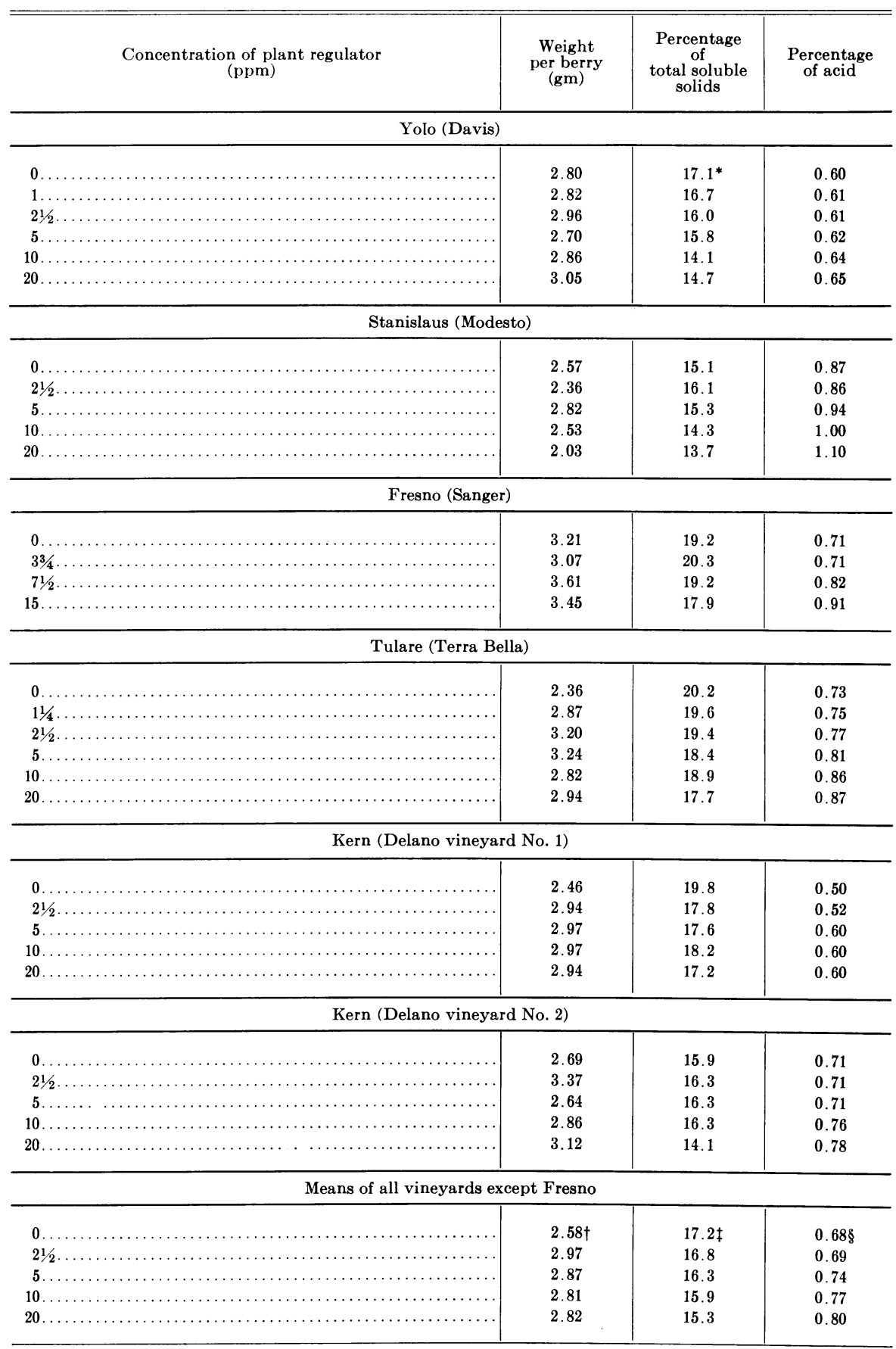

* Significant difference between means for degree Balling readings in 1955 at Davis is 1.6 degrees.

† F-value showed no significant differences for berry size.

Significant difference between means for degree Balling readings at 5 per cent is 0.92

Significant difference between means for percentage of acid at 5 per cent is 0.06 . 
TABIE 5

EFFECT OF VARIOUS CONCENTRATIONS OF BENZOTHIAZOL-2-OXYACETIC ACID ON THOMPSON SEEDLESS GRAPES IN VARIOUS

LOCATIONS IN 1956

\begin{tabular}{|c|c|c|c|}
\hline $\begin{array}{l}\text { Concentration of plant regulator } \\
(\mathrm{ppm})\end{array}$ & $\begin{array}{l}\text { Weight } \\
\text { per berry } \\
(\mathrm{gm})\end{array}$ & $\begin{array}{l}\text { Percentage } \\
\text { of } \\
\text { total soluble } \\
\text { solids }\end{array}$ & $\begin{array}{l}\text { Percentage } \\
\text { of acid }\end{array}$ \\
\hline \multicolumn{4}{|l|}{ Yolo (Davis) } \\
\hline 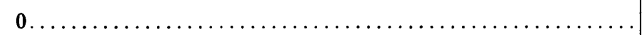 & 2.54 & 18.4 & 0.58 \\
\hline $1 \ldots \ldots \ldots \ldots \ldots \ldots \ldots \ldots \ldots \ldots \ldots \ldots \ldots$ & 2.57 & 19.2 & 0.63 \\
\hline $21 / 2 \ldots \ldots \ldots \ldots \ldots \ldots \ldots \ldots \ldots \ldots \ldots \ldots \ldots \ldots \ldots \ldots \ldots \ldots$ & 2.41 & 16.3 & 0.71 \\
\hline 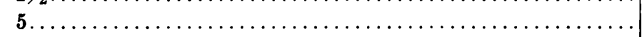 & 3.24 & 18.3 & 0.67 \\
\hline 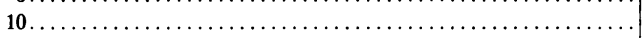 & 2.69 & 15.6 & 0.77 \\
\hline $15 \ldots \ldots \ldots \ldots \ldots \ldots \ldots \ldots \ldots \ldots \ldots \ldots \ldots \ldots \ldots \ldots \ldots \ldots \ldots$ & 2.84 & 16.4 & 0.84 \\
\hline 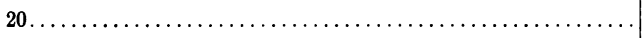 & 2.67 & 14.1 & 0.91 \\
\hline
\end{tabular}

Stanislaus (Ceres)

\begin{tabular}{|c|c|c|c|}
\hline 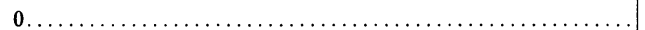 & 1.76 & 19.8 & 0.55 \\
\hline 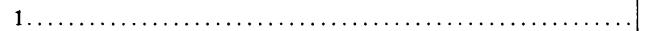 & 1.59 & 19.1 & 0.69 \\
\hline $21 / 2 \ldots \ldots \ldots \ldots \ldots \ldots \ldots \ldots \ldots \ldots \ldots \ldots \ldots \ldots \ldots \ldots \ldots$ & 1.50 & 18.8 & 0.72 \\
\hline 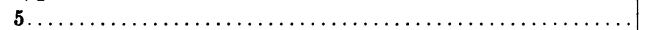 & 1.73 & 17.6 & 0.81 \\
\hline 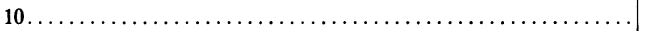 & 1.57 & 17.3 & 0.85 \\
\hline 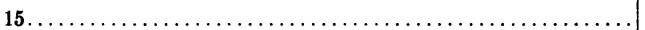 & 1.52 & 18.1 & 0.85 \\
\hline
\end{tabular}

Fresno (Biola)

\begin{tabular}{|c|c|c|c|}
\hline $0 \ldots$ & 2.69 & 19.8 & 0.63 \\
\hline 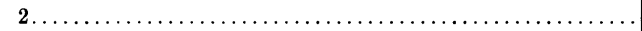 & 2.55 & 18.7 & 0.71 \\
\hline 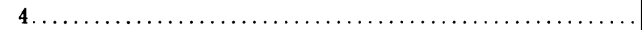 & 3.05 & 17.6 & 0.73 \\
\hline 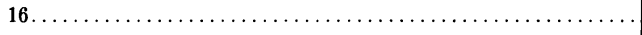 & 2.44 & 15.7 & 0.92 \\
\hline
\end{tabular}

Fresno (Del Rey)

\begin{tabular}{|c|c|c|c|}
\hline 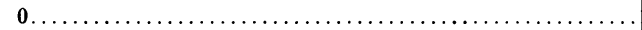 & 2.83 & 21.7 & 0.64 \\
\hline 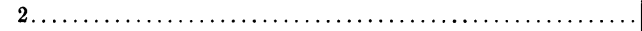 & 2.35 & 17.8 & 0.69 \\
\hline 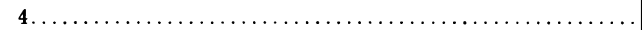 & 2.85 & 19.8 & 0.72 \\
\hline 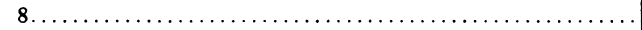 & 2.92 & 19.1 & 0.80 \\
\hline 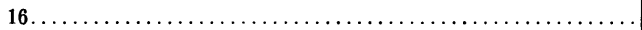 & 2.53 & 17.9 & 0.87 \\
\hline
\end{tabular}

cut off in the berry thinning. Fruit was picked on September 15, when fruit sprayed with BOA at $20 \mathrm{ppm}$ appeared greener than that of other treatments. All concentrations of regulator decreased degree Balling and increased percentage of acid (table 4 ).

Vines in vineyard No. 2 were similar to those of vineyard No. 1 . The treatment was the same. The data obtained from grapes harvested on September 15 were very similar to data of vineyard No. 1 (table 4).

\section{Results in 1956}

In 1956 experiments were carried on in Yolo, Stanislaus, and Fresno counties. At Davis (Yolo County) the 1955 experiment was repeated, except 
that the concentration of $15 \mathrm{ppm}$ was also used. Cluster and berry thinning were done on June 1, eane girdling on June 8, and spraying on June 13. Fruit was harvested on September 21. The data (table 5) show that BOA at concentrations from 10 to $20 \mathrm{ppm}$ depressed the degree Balling reading and resulted in a high retention of acid.

In an experiment in Stanislaus County (Ceres) ungirdled, unthinned vines bearing from 50 to 55 clusters were used. Vines were sprayed on June 8 , five vines per treatment. Fruit was harvested on September 21. BOA at concentrations from 1 to $15 \mathrm{ppm}$ retarded maturation (table 5).

At Biola in Fresno County, girdled vines were only lightly thinned by cutting off the apical one eighth of each cluster. A late crop was desired. Sprays were applied on June 14, and harvesting done on September 6. At Del Rey a similar vineyard was used for the same experiment. Spraying and harvesting were done on the same date as for the Biola vineyard. In both experiments maturation was retarded (table 5).

\section{Effect of Time of Spraying of Benzothiazol-2-oxyacetic Acid (BOA) on Maturation}

Previous experiments with $\mathrm{BOA}$ showed that the stage of development of the fruit was closely associated with its response to the regulator (4). It was shown that applications made four or five weeks after normal berry

TABLE 6

DATA AT HARVEST FOR GIRDLED THOMPSON SEEDLESS GRAPES AT DAVIS, CALIFORNIA, FROM CANES SPRAYED AT DIFFERENT TIMES WITH BOA AT CONCENTRATIONS OF 20 PPM

(Average of 10 replicate canes)

\begin{tabular}{|c|c|c|c|}
\hline Time of treatment & $\begin{array}{l}\text { Weight } \\
\text { per berry } \\
(\mathrm{gm})\end{array}$ & $\begin{array}{l}\text { Degree Balling } \\
\text { reading }\end{array}$ & $\begin{array}{l}\text { Percentage } \\
\text { of acid }\end{array}$ \\
\hline Not sprayed......... & 2.58 & 18.1 & 0.47 \\
\hline Sprayed June 10 . . & 2.53 & 14.6 & 0.69 \\
\hline Sprayed June 27 . & 2.96 & 14.6 & 0.69 \\
\hline Sprayed July 11. & 3.03 & 14.5 & 0.72 \\
\hline Sprayed July $28 \ldots$ & 3.29 & 16.0 & 0.58 \\
\hline Sprayed August $8 \ldots$ & 2.96 & 16.6 & 0.53 \\
\hline Sprayed August $30 \ldots \ldots \ldots \ldots \ldots \ldots \ldots \ldots \ldots \ldots \ldots \ldots \ldots \ldots \ldots \ldots \ldots$ & 2.70 & 17.1 & 0.51 \\
\hline L.S.D. at 5 per cent level. & 0.36 & 1.8 & 0.06 \\
\hline
\end{tabular}

shatter, when the degree Balling was about 6 , usually resulted in greater retardation in maturation than did applications made either immediately after berry shatter or after the fruit attained a degree Balling reading of 14 or more.

The purpose of this experiment performed in 1955 at Davis was to repeat this work, using more stages of development. Spraying was done on each of six different dates:

June 10, after shatter of impotent flowers following bloom

June 27, when the larger berries were 7 to $8 \mathrm{~mm}$ in diameter 
July 11, when larger berries were 8 to $10 \mathrm{~mm}$ in diameter and the degree Balling about 6.2

July 28, when the degree Balling was 9.1 and percentage of acid 3.61

August 8, when the degree Balling was 13.3 and percentage of acid 1.40 ; and on

August 30, when the degree Balling was 15.4 and the percentage of acid 0.79 .

Fruit was harvested on September 21. In this experiment the sprayings on June 27, July 11, July 28, and August 8 increased weight of berry (table 6 ). However, berries sprayed on July 11 appeared greener in color than by other treatments. The sprayings on June 10, June 27, and July 11 retarded maturation to about the same degree, although the greatest retardation resulted from the latter application. After July 11, the effect on maturation became progressively less. Therefore, to obtain greatest delay in maturation, one should spray Thompson Seedless within one month after berry shatter. It is necessary to spray within about four weeks after shatter, as later spraying may remove some of the bloom.

\section{Effect of Benzothiazol-2-oxyacetic Acid on Rate of Maturation}

The purpose was to compare the rates of maturation on unsprayed vines with vines sprayed with $\mathrm{BOA}$ and to determine the difference in final ripeness between sprayed and unsprayed fruit. On June 10, 1955, 20 vines were

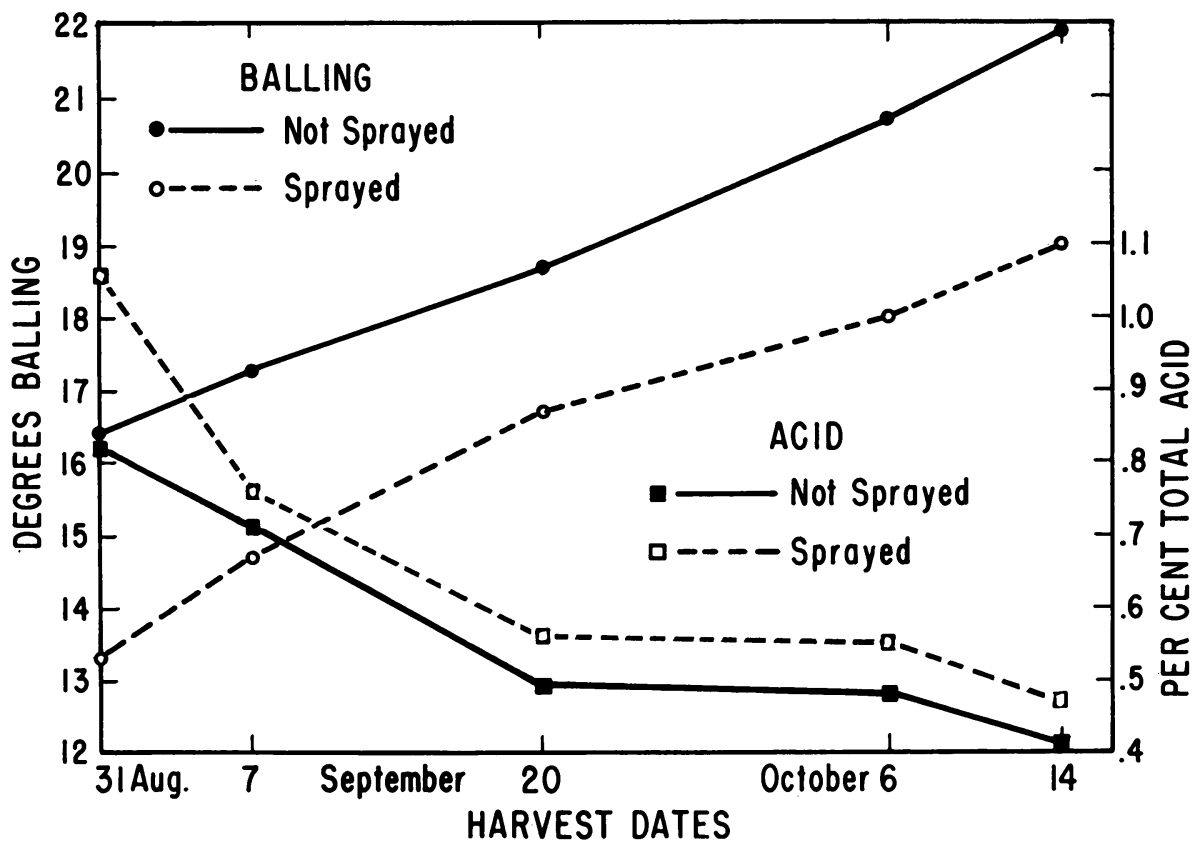

Fig. 1. Average degree Balling readings and percentages of total acid, taken at intervals from untreated Thompson Seedless grapes and from grapes sprayed with BOA at 20 ppm at Davis. The L. S. D. at the 5 per cent level between means on any given date for degree Balling is 2.5 and for percentage of total acid is 0.09 . 
cluster thinned to about 20 clusters per vine, berry thinned by cutting off the apical half of the clusters, and trunk girdled. Two vines were sprayed with $\mathrm{BOA}$ at a concentration of $20 \mathrm{ppm}$. This was replicated five times. Another set of vines was not sprayed. Samples of fruit were taken on August 31, September 7, September 20, October 6, and October 14 (fig. 1).

The sprayed and unsprayed samples had the same physical appearance through the September 20 picking, but on October 6 the sprayed berries possessed a greener color than the controls. By October 14, rot was developing in both sprayed and unsprayed grapes.

The data show that berry size was not affected by the spray. The degree Balling of the sprayed fruit was retarded 19 days or more over the controls, and sprayed fruit never attained the degree of ripeness of the controls (fig. 1).

\section{DISCUSSION}

The plant regulator 4-CPA resulted in some delay of maturity in only about half of the experiments. The explanation as to why no delay occurred in some experiments with this compound is unknown at this time. Perhaps level of crop, climate, and previous history of the vine are involved.

The berries on heavily overcropped vines failed to enlarge as a result of application of 4-CPA. This agrees with girdling experiments (1) which also failed to increase size of berry in overcropped vines as a result of girdling.

The greatest delay in maturity as a result of application of BOA resulted from the treatment on July 11. This agrees with previous experiments done in 1954 at Davis and Delano (4). However, spraying soon after the shatter of impotent berries following flowering gave almost as much delay as did spraying on July 11. In the 1954 work, early spraying resulted in much less delay than did spraying in the middle of the season. The climatic differences in 1954 and 1955 may account for this difference. The early portion of the growing season of 1955 was much cooler than that in 1954, while the temperatures during the months of August, September, and October were higher in 1955 than in 1954.

The degree Balling of grapes sprayed with BOA was delayed about three weeks over that of the controls in 1955. A similar experiment in 1954 delayed the degree Balling reading only about 12 days (4). It is possible that grapes sprayed with BOA will never attain the degree Balling made by unsprayed vines in any season.

\section{SUMMARY}

1. Experiments in which foliage and/or clusters of Thompson Seedless were treated with 4-chlorophenoxyacetic acid (4-CPA) demonstrated that an almost maximum increase in size of berry can be obtained by compound which is absorbed by the leaves. The greatest increase was obtained by dipping clusters in 4-CPA in addition to spraying foliage.

2. Studies made over a four-year period indicate that in about one half of the experiments 4-CPA results in a slight delay in maturation.

3 . When heavily overcropped vines of Thompson Seedless are sprayed with 4-CPA, the size of berry is increased little or none by applications of the regulator. 
4. Benzothiazol-2-oxyacetic acid (BOA) in the range from 1 to $20 \mathrm{ppm}$ was applied to Thompson Seedless grapes in five counties in California in 1955 and 1956. The compound in the range from 5 to $10 \mathrm{ppm}$ usually retarded maturation as evidenced by a decrease in degree Balling reading and a high retention of total acidity, although high quality fruit developed. Higher concentrations resulted in some misshapen leaves and sometimes in inferior fruit.

5. At Davis BOA was applied to Thompson Seedless at six different stages of development. Fruit sprayed on July 11, when the larger berries were 8 to $10 \mathrm{~mm}$ in diameter and the degree Balling about 6.2, was retarded the most, although sprayings applied between the times of berry shatter and July 11 resulted in almost as much retardation. Applications made later than July 11 resulted in progressively less retardation.

6. At Davis, vines sprayed in 1955 with BOA were retarded in maturation by about 19 days or more over the unsprayed vines. The degree Balling of sprayed fruit never attained the degree Balling of unsprayed fruit.

\section{ACKNOWLEDGMENTS}

The authors express their thanks to the following Extension Agriculturists who aided in the experiments: P. P. Baranek, J. R. Fleming, K. W. Hench, F. L. Jensen, and P. D. La Vine.

\section{LITERATURE CITED}

1. JАCOB, H. E.

1931. Girdling grape vines. California Agr. Ext. Service Cir. 56.

2. WeAver, R. J.

1953. Further studies on effects of 4-chlorophenoxyacetic acid on development of Thompson Seedless and Black Corinth grapes. Amer. Soc. Hort. Sci. Proc. 61:135-43.

3. WEAVER, R. J.

1954. Effect of benzothiazol-2-oxyacetic acid in delaying maturity of grapes. Science $119: 287-88$.

4. WEAVER, R. J.

1955. Use of benzothiazol-2-oxyacetic acid to delay maturity of grapes. Bot. Gaz. 116: 266-73.

5. Weaver, R. J., and W. O. Williams

1950. Response of flowers of Black Corinth and fruit of Thompson Seedless grapes to applications of plant growth-regulators. Bot. Gaz. 11:477-85.

6. WEAVER, R. J., and A. J. WINKLER

1952. Increasing the size of Thompson Seedless grapes by means of 4-chlorophenoxyacetic acid, berry thinning and girdling. Plant Physiol. $27: 626-30$.

7. WINKLER, A. J.

1931. Pruning and thinning experiments with grapes. California Agr. Expt. Sta. Bul. 519. 
The journal Hilgardia is published at irregular intervals, in volumes of about 600 pages. The number of issues per volume varies.

Subscriptions are not sold. The periodical is sent as published only to libraries, or to institutions in foreign countries having publications to offer in exchange.

You may obtain a single copy of any issue free, as long as the supply lasts; please request by volume and issue number from:

Agricultural Publications

Room 22, Giannini Hall

University of California

Berkeley 4, California

The limit to nonresidents of California is 10 separate issues on a single order. A list of the issues still available will be sent on request.

In our publications it is sometimes convenient to use trade names of products or equipment rather than scientific identifications. In so doing it is unavoidable in some cases that similar products which are on the market under other trade names may not be cited. No endorsement of named products is intended nor is criticism implied of similar products which are not mentioned. 


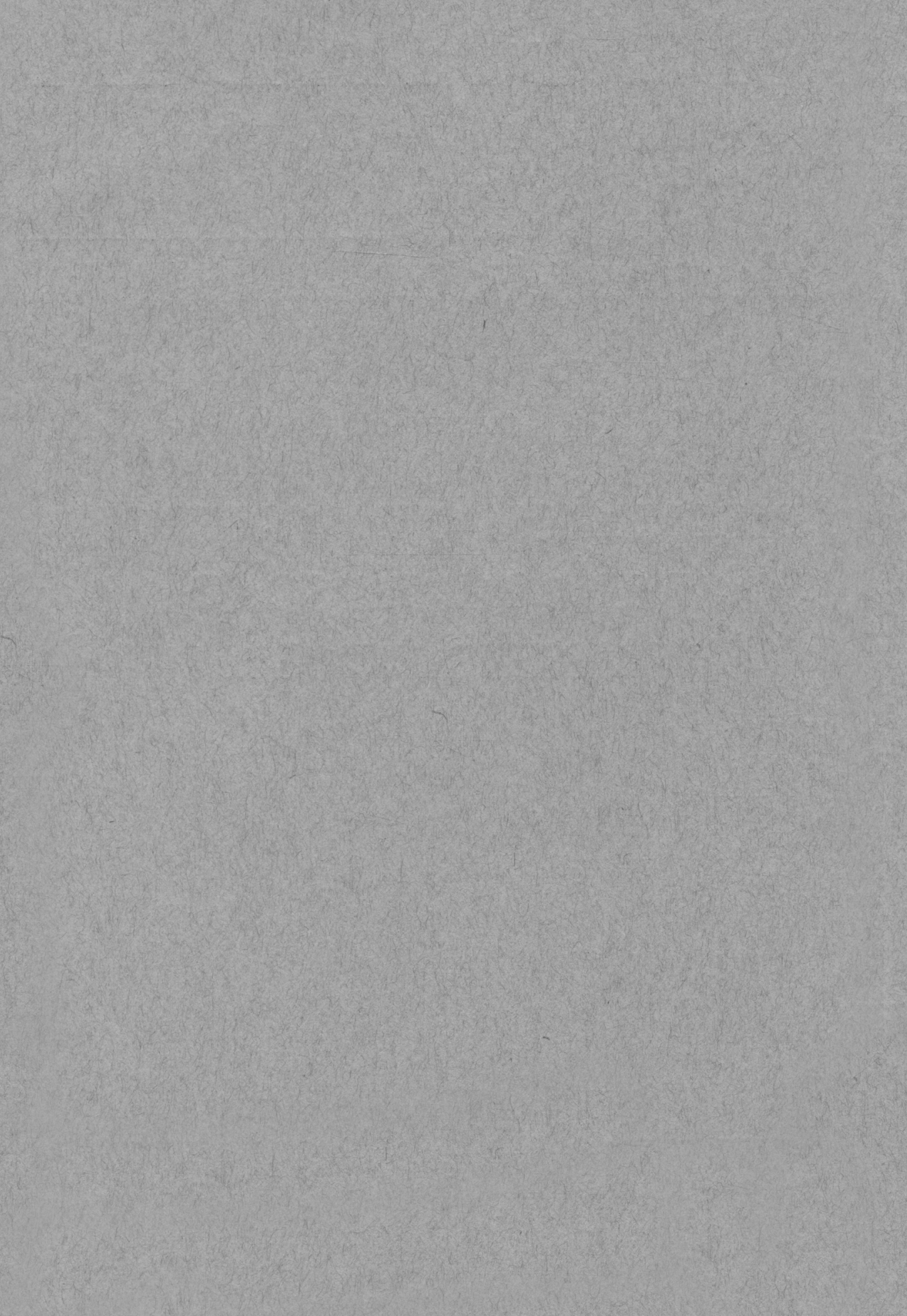

